\title{
Links between microbial biomass and necromass components in the top- and subsoils of temperate grasslands along an aridity gradient
}

\author{
Xinying Zhang ${ }^{\mathrm{a}, \mathrm{b}, 1}$, Guohua Dai ${ }^{\mathrm{a}, 1}$, Tian Ma ${ }^{\mathrm{a}, \mathrm{b}}$, Nana $\mathrm{Liu}^{\mathrm{c}}$, Huifeng $\mathrm{Hu}^{\mathrm{a}}$, Wenhong $\mathrm{Ma}^{\mathrm{d}}$, \\ Jin-Bo Zhang ${ }^{\mathrm{e}}$, Zhiheng Wang ${ }^{\mathrm{c}}$, Francien Peterse ${ }^{\mathrm{f}}$, Xiaojuan Feng ${ }^{\mathrm{a}, \mathrm{b}, *}$ \\ a State Key Laboratory of Vegetation and Environmental Change, Institute of Botany, Chinese Academy of Sciences, Beijing 100093, China \\ ${ }^{\mathrm{b}}$ College of Resources and Environment, University of Chinese Academy of Sciences, Beijing 100049, China \\ ${ }^{\mathrm{c}}$ Institute of Ecology and Key Laboratory for Earth Surface Processes of the Ministry of Education, College of Urban and Environmental Sciences, Peking University, Beijing \\ 100871, China \\ ${ }^{\mathrm{d}}$ School of Ecology and Environment, Inner Mongolia University, Hohhot 010021, China \\ ${ }^{\mathrm{e}}$ School of Geography Sciences, Nanjing Normal University, Nanjing 210023, China \\ ${ }^{\mathrm{f}}$ Department of Earth Sciences, Utrecht University, Utrecht, Netherlands
}

\section{A R T I C L E I N F O}

Handling Editor: Naoise Nunan

Keywords:

Microbial carbon

GDGTs

PLFAs

Amino sugars

Necromass

\begin{abstract}
A B S T R A C T
Microbial carbon has recently been highlighted to play a key role in the formation and persistence of soil organic carbon, bearing significant implications for regulating ecosystem carbon stocks under global changes. However, microbial carbon distribution and the link between biomass and necromass components are poorly understood in natural soils, especially at depth. Here, we employ various microbial biomarkers, including phospholipid fatty acids (PLFAs), amino sugars and glycerol dialkyl glycerol tetraethers (GDGTs), to investigate the spatial distribution patterns of microbial biomass and necromass components in the top- $(0-10 \mathrm{~cm})$ versus subsoils (30-50 cm) across Chinese temperate grasslands along an aridity gradient. We find that bacterial necromass components are better preserved relative to bacterial biomass in the sub- than topsoil, possibly due to a stronger association of microbial necromass with calcium and/or lower nitrogen competition between plants and microbes at depth in these neutral-to-alkaline soils. As a result, there is a stronger link between bacterial necromass components (especially for core lipid branched GDGTs and muramic acid) and their producers (reflected by intact polar lipid-derived branched GDGTs) in the sub- than topsoil, while such a trend is not observed for fungior archaea-derived components. Furthermore, using linear mixed effect model analyses, we find that aridity index best explains the concentration variance of most microbial biomarkers in the topsoil, whereas edaphic properties (i.e., $\mathrm{pH}$ and macronutrients) also contribute significantly to their variance in the subsoil. These findings highlight different links between microbial necromass and biomass components and distinct preservation mechanisms for microbial carbon at different soil depths, which is crucial for improved understanding of microbial carbon sequestration potentials at different depths in a changing environment.
\end{abstract}

\section{Introduction}

Microbial-derived carbon components have recently been highlighted to play a key role in the formation and persistence of soil organic carbon (SOC; Miltner et al., 2012; Cotrufo et al., 2013; Liang et al., 2015; 2017;; Kallenbach et al., 2016; Ma et al., 2018). Soil microbes, through their catabolic and anabolic activities, convert decomposable organic matter into microbial biomass and byproducts (such as polysaccharide extracellular substances), which subsequently stabilize as microbial-processed compounds and/or necromass in the soil (Liang et al., 2015). These microbial components (especially necromass) tend to be closely associated with mineral surfaces (KögelKnabner et al., 2008; Sollins et al., 2009) and are considered to be relatively stable, accumulate under repeated community turnover and contribute to the buildup of persistent SOC (Cotrufo et al., 2013; Ma et al., 2018). The above processes, recently summarized as soil "microbial carbon pump" (Liang et al., 2017), have important implications for understanding and predicting the response of the relatively stable

${ }^{*}$ Corresponding author at: State Key Laboratory of Vegetation and Environmental Change, Institute of Botany, Chinese Academy of Sciences, Beijing 100093, China.

E-mail address: xfeng@ibcas.ac.cn (X. Feng).

${ }^{1}$ Equal contribution to this work. 
soil carbon pools to global changes (Schmidt et al., 2011) and are hence gaining great research momentum at the moment. However, the spatial distribution of microbial-derived carbon components and the corresponding driving factors are not well investigated in natural soils, hindering a clear understanding of mechanisms regulating microbialmediated SOC accumulation across natural environmental gradients.

Recently, utilizing a continental-scale grassland transect across China and Mongolia, we have found increasing SOC-normalized concentrations of amino sugars (i.e., biomarkers for microbial necromass in the soil; Joergensen, 2018) with decreasing aridity and increasing SOC content, accompanied by decreasing concentrations of plant-derived lignin phenols in the surface soils (Ma et al., 2018). The contrasting distribution of microbial- versus plant-derived biomarkers implies an enrichment of microbial necromass with SOC accrual due to elevated microbial conversion of plant carbon with increasing soil moisture in the semi-arid grassland, thereby providing large-scale evidence for the key role of microbial necromass in SOC accumulation (Ma et al., 2018). However, as this previous study only examined the topsoil $(0-10 \mathrm{~cm})$, microbial carbon distribution and preservation remain to be investigated in the subsoil $(>30 \mathrm{~cm})$ across the Chinese temperate grasslands. The subsoil harbors more than half of global SOC stocks (Rumpel et al., 2012) and has different organic matter sources, microbial communities and edaphic properties compared to the topsoil (Rumpel et al., 2012). Given increasing substrate (or nutrient) constraints with soil depth, microbial communities are known to be less active and/or have a lower growth rate in the subsoil (Fierer et al., 2003a; Liang and Balser, 2008; Sradnick et al, 2014), potentially leading to lower carbon accumulation efficiency (Jia et al., 2017) compared to the topsoil. Alternatively, subsoils are carbon-unsaturated in terms of reactive mineral surfaces and exhibit a higher sequestration potential for new carbon relative to the topsoil (Schiedung et al., 2019). Therefore, it is important to investigate whether microbial components exhibit different spatial distribution patterns and preservation along soil depths. Such information is important for predicting soil carbon sequestration potential and its response to global changes.

To explore the preservation of microbial necromass in natural soils, it is necessary to examine its occurrence and abundance in relation to the biomass of its microbial producers. Amino sugars, as classic markers for microbial necromass originating from cell walls (Zhang and Amelung, 1996; Glaser et al., 2006), are usually compared with phospholipid fatty acids (PLFAs) that serve as biomarkers for living fungal and bacterial communities (Frostegård and Bååth, 1996; Bardgett and McAlister, 1999; Zhang et al., 2019). Furthermore, archaea also represent an important part of the soil microbial community (Günther et al., 2014; Maestre et al., 2015). The components of archaeal membranes differ from those of fungi and bacteria (Albers and Meyer, 2011) and are therefore not represented by PLFA analysis, although archaea do potentially contribute to microbial necromass (amino sugars) in the soil (Kandler and König, 1998). Instead, glycerol dialkyl glycerol tetraethers (GDGTs) originating from the membranes of archaea and certain bacteria thriving in soils (Weijers et al., 2006a; 2007) can provide a complementary tool to assess the distribution of the microbial groups that are not captured by PLFAs. Specifically, isoprenoid GDGTs (iGDGTs) are produced by archaea (in particular, Thaumarchaeota; Xie et al., 2012; Yang et al., 2014) while branched GDGTs (brGDGTs) are synthesized by certain bacteria (in particular, Acidobacteria; Sinninghe Damsté et al., 2011). Similar to PLFAs, GDGTs released from intact polar lipids (IPLs) are markers for living biomass (Logemann et al., 2011; Sinninghe Damsté et al., 2012;), as their polar headgroup is considered to be lost within days upon cell death (Harvey et al., 1986; White et al., 1979). By comparison, GDGT core lipids (CLs) without the polar headgroup are considered to represent the pool of 'dead' components (with a turnover time of $\sim 20$ years; Weijers et al., 2010; Sinninghe Damsté et al., 2012). Hence, although originating from distinct parts of microbial cells and from (partly) different communities, CL GDGTs and amino sugars can be used to assess the distribution and preservation of microbial necromass components relative to biomass (i.e., PLFAs and IPL-derived GDGTs) throughout the soil. Nevertheless, few studies have compared the presence of and relations between these microbial components in soils at large spatial scales and different depths.

Here, employing the above-mentioned biomarkers (IPL-derived GDGTs and PLFAs for biomass; CL GDGTs and amino sugars for necromass; summarized in Table S1), we compare the distribution and relationships of microbial biomass versus necromass carbon components in the temperate grassland soils of Inner Mongolia along an aridity gradient. The overall objective of this study is to examine links between microbial necromass and biomass components and the preservation mechanisms for microbial carbon at different soil depths in order to improve our ability to understand, model, and predict soil carbon sequestration. Soils in this arid and semiarid region are alkaline ( $\mathrm{pH}$ of 7.7-10.4) and coarse-textured, covered by three main vegetation types (desert steppe, typical steppe and meadow steppe with increasing moisture; Liu et al., 2020). A comprehensive dataset of environmental variables is compiled to disentangle climatic, edaphic and vegetation influences on biomarker abundances and composition in the top$(0-10 \mathrm{~cm})$ versus subsoils $(30-50 \mathrm{~cm})$. Based on our previous studies along this aridity gradient (e.g., Ma et al., 2018; Liu et al., 2020) and the aforementioned physiochemical contrasts between top- and subsoils, we hypothesize that: (1) while climate (aridity) plays a key role in the abundance of microbial necromass in the topsoil, edaphic properties are more important in the subsoil; and (2) microbial necromass components are better preserved relative to biomass in the sub- than topsoil due to stronger physical-chemical protection provided by subsoils.

\section{Materials and methods}

\subsection{Study area}

This study covers an aridity gradient along a temperate grassland transect extending $>1200 \mathrm{~km}$ in the arid and semiarid regions of northern China (Fig. S1). Mean annual temperature (MAT) is -2.1 to $7.6{ }^{\circ} \mathrm{C}$ (Fig. 1a). Mean annual precipitation (MAP) ranges from 173 to $415 \mathrm{~mm}$ with the aridity index, i.e., the ratio of MAP to potential evapotranspiration, being $0.18-0.56$ (Fig. 1b-c; WorldClim database; http://www.worldclim.org). Soils along this transect are classified as Chernozems, Kastanozems and Calcisols according to IUSS Working Group WRB (2015). The three dominant vegetation types are meadow steppe (dominated by Stipa baicalensis and Leymus chinensis), typical steppe (Stipa grandis and Stipa krylovii) and desert steppe (Stipa klemenzii and Stipa breviflora). It should be noted that vegetation types largely coincide with soil types in this study. A more detailed description of the study area can be found in Chen et al. (2015) and Ma et al. (2018).

\subsection{Sampling and bulk measurements}

A total of 32 sites along the transect were selected for soil sampling and biomass survey in the summer (July-August) of 2015. Aboveground biomass was harvested from five quadrats $(1 \mathrm{~m} \times 1 \mathrm{~m})$ at the center and four corners of each site $(10 \mathrm{~m} \times 10 \mathrm{~m})$ and dried at $65{ }^{\circ} \mathrm{C}$ before weight measurement. The number of plant species was counted and species richness is represented by the total number of species for each quadrat. Site-average values of five quadrants were used for each site. Top- $(0-10 \mathrm{~cm})$ and subsoils $(30-50 \mathrm{~cm})$, corresponding to A and B (calcic) horizon, respectively, were retrieved from three soil cores (diameter of $5 \mathrm{~cm}$ ) along the diagonal of each quadrat. Soils from the same depth of each quadrat were mixed thoroughly in situ. After passing through a 2-mm sieve and removal of visible roots, soils were divided into two parts: one part was stored at $-80{ }^{\circ} \mathrm{C}$ for microbial membrane lipid analysis (including PLFAs and GDGTs) and the other part was air-dried for the determination of bulk chemical parameters. In this study, equal proportions of soils from each quadrant 
(a)

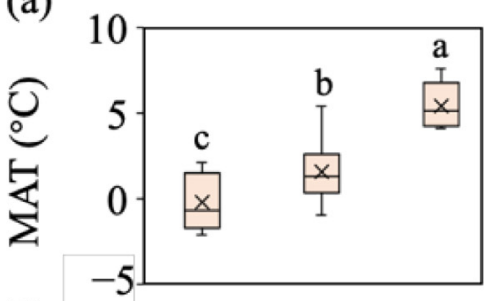

(d)

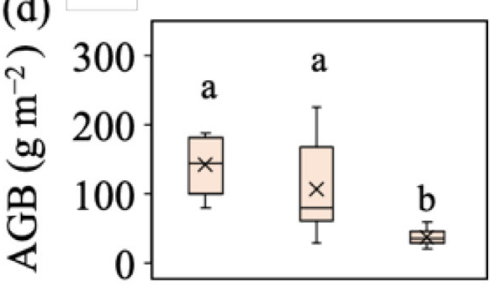

(g)

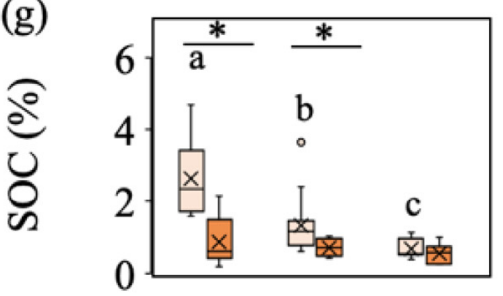

(j)

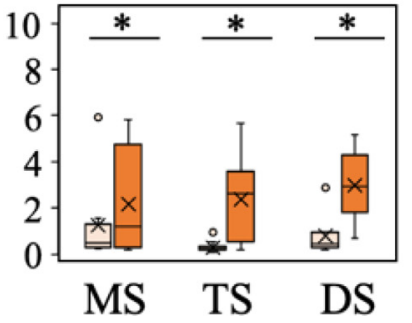

(b)

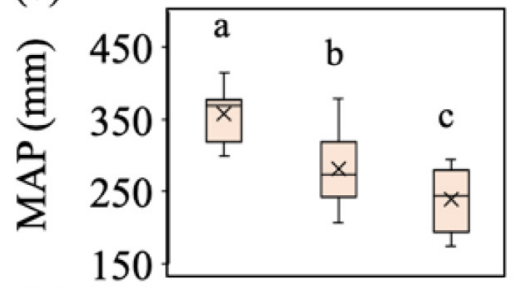

(e)

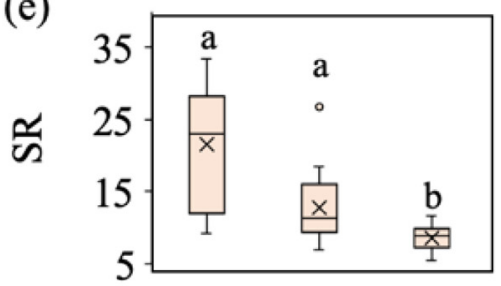

(h)

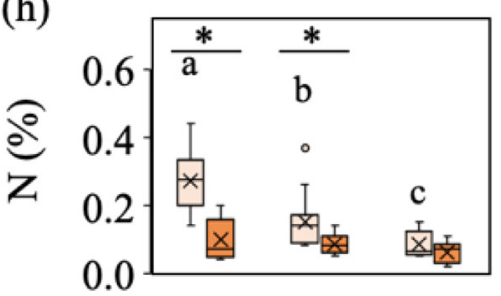

(k)

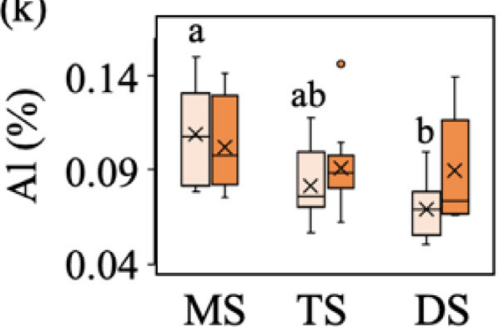

(c)

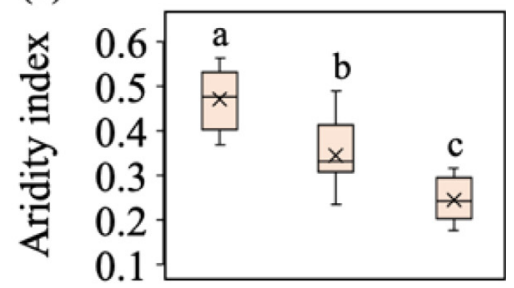

(f)

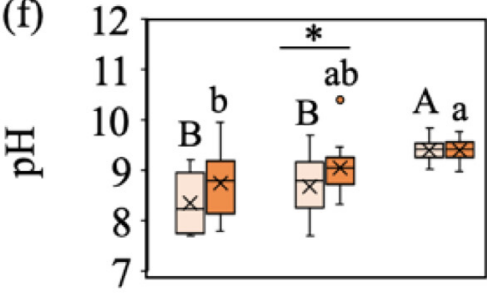

(i)

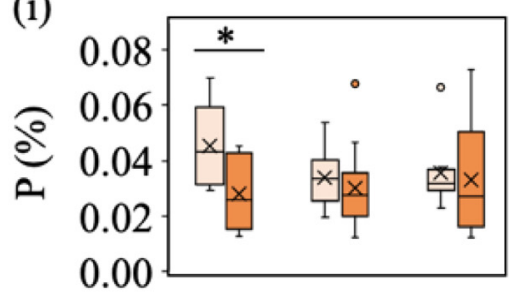

(l)

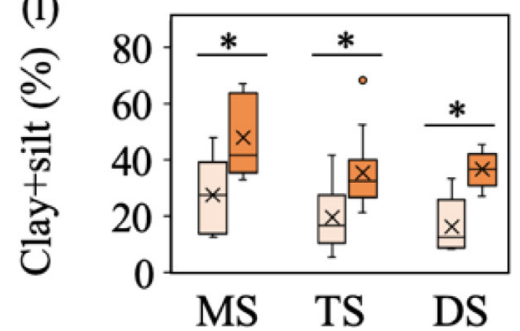

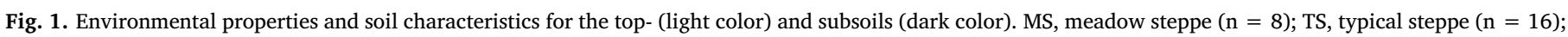

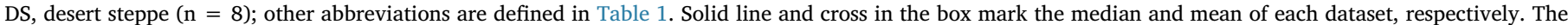

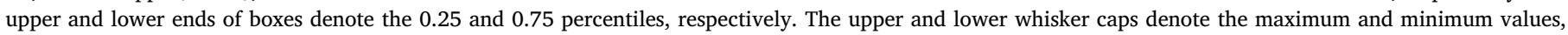
respectively. Dots denote outliners. Letters indicate different levels among vegetation types $(p<0.05)$. * indicates difference between depths $(p<0.05)$.

were homogenized as a composite sample for each site. Although this approach cannot provide information on the spatial variability within the sites, it can keep the analytical effort within manageable limits and provide results which are representative of a larger area at each site $(10 \mathrm{~m} \times 10 \mathrm{~m})$. Total carbon and total nitrogen $(\mathrm{N})$ concentrations of soil samples were measured by combustion using an elemental analyser (Vario EL III, Elementar, Hanau, Germany). SOC was calculated as total carbon subtracted by inorganic carbon, with the latter analyzed volumetrically by reaction with hydrochloric acid $(\mathrm{HCl})$ as previously described (Dai et al., 2018). Total phosphorus (P) content was determined by the molybdate colorimetric test after perchloric acid digestion (Rowland and Haygart, 1997). Soil pH was measured at a soil:water ratio of 1:2.5 (w:v). Dithionite-extractable iron (Fe), aluminum (Al) and calcium $(\mathrm{Ca})$ were extracted using the citrate-bicarbonate-dithionite method (Mehra and Jackson, 1960) and examined on an inductively coupled plasma emission spectrometer (Thermo ICAP6300, USA). Soil texture was measured by Malvern Mastersizer 2000 (Malvern Instruments Ltd., UK) after removal of organic matter and carbonates using hydrogen peroxide and $\mathrm{HCl}$, respectively (Sun et al., 2011).

\subsection{Biomarker analysis}

\subsubsection{GDGTs}

GDGTs were extracted using a modified Bligh-Dyer method (Bligh and Dyer, 1959; Tierney et al., 2012). Briefly, freeze-dried soils (6-7 g for topsoil and 12-14 $\mathrm{g}$ for subsoil) were extracted three times by ultrasonication in a mixture of dichloromethane, methanol, and $0.1 \mathrm{M}$ phosphate buffer (2:1:0.8, v:v) at pH $7.4\left(5 \mathrm{~mL} \mathrm{~g}^{-1}\right.$ soil). The supernatant was collected after centrifugation. The phosphate buffer was then replaced by trichloroacetic acid $(50 \mathrm{mM})$ and the soil was extracted twice more. All extracts were combined and concentrated using a rotary evaporator, and separated on a silica gel column $(0.5 \mathrm{~cm}$ i.d.; $7 \mathrm{~cm}$ in length) into CL and IPL fractions eluting with hexane:ethyl acetate (1:1, v:v; $6 \mathrm{~mL})$ and methanol $(10 \mathrm{~mL})$, respectively. The IPL fraction was split into two parts for GDGT and PLFA analyses (Section 2.3.2). For GDGTs, $50-70 \%$ (Fig. S2) of the IPL fraction was hydrolyzed with a mixture $(2 \mathrm{~mL})$ of $6-\mathrm{M} \mathrm{HCl}$, methanol and dichloromethane (1:9:1, v:v:v) at $70{ }^{\circ} \mathrm{C}$ for $24 \mathrm{~h}$ to cleave the polar head group. Both CL and hydrolyzed IPL fractions were dried under nitrogen gas and stored at $-20{ }^{\circ} \mathrm{C}$ until further analysis.

After addition of a $\mathrm{C}_{46}$ GDGT internal standard (Huguet et al., 2006), the GDGTs were re-dissolved in hexane:isopropanol (99:1, v:v), and filtered through a $0.45-\mu \mathrm{m}$ PTFE filter. Analysis of GDGTs was achieved following Hopmans et al. (2016) on an Agilent 1260 Infinity ultra-high performance liquid chromatography (UPLC) coupled to an Agilent 6130 single quadrupole mass spectrometer using two silica Waters Acquity UPLC HEB Hilic columns $(1.7 \mu \mathrm{m}, 2.1 \mathrm{~mm} \times 150 \mathrm{~mm})$ at $30{ }^{\circ} \mathrm{C}$, with a guard column $(7.5 \times 2.1 \mathrm{~mm}, 5 \mu \mathrm{m})$ of the same 
material preceding both. An injection volume of $10 \mu \mathrm{L}$ and a flow rate of $0.2 \mathrm{~mL} \mathrm{~min}^{-1}$ were used. Samples were eluted with $82 \%$ hexane and $18 \%$ hexane:isopropanol $(9: 1, v: v)$ for $25 \mathrm{~min}$, followed by a linear gradient to $70 \%$ hexane, 30\% hexane:isopropanol $(9: 1, v: v)$ for $25 \mathrm{~min}$, and then to $100 \%$ hexane:isopropanol $(9: 1, v: v)$ in $30 \mathrm{~min}$. Detection was achieved in selected ion monitoring (SIM) mode using $\mathrm{m} / \mathrm{z} 1302$, 1300, 1298, 1296, and 1292 for iGDGTs (including GDGTs I-Ic, II-IIc and III-IIIc; Fig. S3), $m / z$ 1050, 1048, 1046, 1036, 1034, 1032, 1022, 1020 and 1018 for brGDGTs (including the 5- and 6-methyl isomers of GDGT 0-3, crenarchaeol and crenarchaeol'; Fig. S3), and $m / z 744$ for the internal standard (Fig. S3). The GDGTs were quantified assuming similar response factors for all GDGTs and the internal standard.

Total GDGTs are summarized as brGDGTs and iGDGTs. The ratio of iGDGTs to brGDGTs (i/br) is indicative of the proportion of archaealversus bacterial-derived GDGTs. The ratio of IPL-derived to CL GDGTs (IPL/CL GDGTs) represents the fraction of (recently) active GDGT producers as part of the total pool of GDGTs. Alternatively, the percentage of IPL-derived GDGTs (\%IPL) in the total pool of GDGTs (i.e., CL and IPL-derived GDGTs) is calculated for both iGDGTs and brGDGTs for convenience. The ratio of GDGT-0/crenarchaeol is also calculated to assess aeration of the soil (Wang et al., 2012), where values $>2$ indicate a substantial contribution of GDGT-0, which is produced by methanogens under anoxic conditions (Blaga et al., 2009).

\subsubsection{PLFAs}

PLFAs in the topsoil were analyzed in a previous study (Liu et al., 2020). For the subsoil, 30\% of the IPL fraction (Section 2.3.1) was blown to dryness under nitrogen gas. PLFAs in the IPL fraction were converted into fatty acid methyl esters (FAMEs) by alkaline methanolysis (Guckert et al., 1985) and recovered with a hexane and dichloromethane mixture (4:1, v/v) three times, spiked with cholestane as an internal standard and evaporated to dryness under nitrogen gas. FAMEs were re-dissolved in $200 \mu \mathrm{L}$ hexane and analyzed on a Trace 1310 gas chromatograph (GC) coupled to an ISQ mass spectrometer (MS; Thermo Fisher Scientific, USA) using a DB-5MS column $(30 \mathrm{~m} \times 0.25 \mathrm{~mm}$ i.d., film thickness, $0.25 \mu \mathrm{m}$ ) for separation. The oven temperature was held at $100{ }^{\circ} \mathrm{C}$ for $5 \mathrm{~min}$, increased to $240{ }^{\circ} \mathrm{C}$ at a rate of $4{ }^{\circ} \mathrm{C} \mathrm{min}^{-1}$ with helium as the carrier gas $\left(1.2 \mathrm{~mL} \mathrm{~min}^{-1}\right)$. Spectra were obtained by scanning over the range of 50-650 Daltons in an electron impact ionization mode at $70 \mathrm{eV}$. Individual PLFAs were quantified by comparison with the internal standard in the total ion current.

Fatty acids are designated according to the standard PLFA nomenclature (Guckert et al., 1985). In this study, Gram-positive (G+) bacteria are represented by PLFAs a13:0, i13:0, i14:0, a15:0, i15:0, i16:0, $a 17: 0$, i17:0, and Gram-negative $(\mathrm{G}-)$ bacteria are represented by

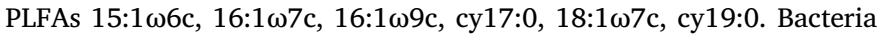
are represented by $\mathrm{G}+$ and $\mathrm{G}-$ bacterial PLFAs and other general bacterial PLFAs (14:0, 15:0, 16:0, 17:0, 18:0). Fungi are represented by PLFAs 18:1 $\omega 9 \mathrm{c}, 18: 2 \omega 6 \mathrm{c}, 18: 3 \omega 6 \mathrm{c}$ and $16: 1 \omega 5 \mathrm{c}$. Microbial biomass is represented by total PLFAs (Feng and Simpson, 2009; Willers et al., 2015), including bacteria, fungi and actinomycetes (PLFAs 10Me16:0, 10Me17:0, 10Me18:0). The ratios of fungal and bacterial PLFAs (F/B) and $\mathrm{G}+/ \mathrm{G}-$ bacterial PLFAs are also assessed.

\subsubsection{Amino sugars}

Amino sugars were analyzed following the classic method of Zhang and Amelung (1996). Briefly, $\sim 0.5 \mathrm{~g}$ of air-dried soil $(<2 \mathrm{~mm}$ ) was hydrolyzed with $10 \mathrm{~mL}$ of $6 \mathrm{M} \mathrm{HCl}$ at $105^{\circ} \mathrm{C}$ for $8 \mathrm{~h}$. The cooled sample was amended with $100 \mu \mathrm{g}$ of myo-inositol as a surrogate standard, filtered, evaporated to dryness at $50-53{ }^{\circ} \mathrm{C}$ under reduced pressure and redissolved in $5 \mathrm{~mL}$ of MilliQ water with the $\mathrm{pH}$ adjusted to 6.6-6.8 using $1 \mathrm{M}$ potassium hydroxide. Precipitates were discarded after centrifugation $(1000 \times g, 10 \mathrm{~min})$ and the supernatant was freeze-dried. Amino sugars were re-dissolved in methanol and separated from salts by centrifugation. After the addition of a quantitative standard (methyl- glucamine), amino sugars were transformed into aldononitrile derivatives by heating in $0.3 \mathrm{~mL}$ of a derivatization reagent containing $32 \mathrm{mg} \mathrm{mL}^{-1}$ of hydroxylamine hydrochloride and $40 \mathrm{mg} \mathrm{mL}^{-1}$ of 4 (dimethylamino) pyridine in pyridine and methanol mixture (4:1; v:v) at $75{ }^{\circ} \mathrm{C}$ for $30 \mathrm{~min}$ (Guerrant and Moss, 1984; Glaser et al., 2004). The derivatives were further acetylated with $1 \mathrm{~mL}$ of acetic anhydride at $75-80{ }^{\circ} \mathrm{C}$ for $20 \mathrm{~min}$ and mixed with $1.5 \mathrm{~mL}$ of dichloromethane after cooling. Excessive derivatization reagents were removed by extracting with $\mathrm{HCl}(1 \mathrm{M})$ and MilliQ water. The dichloromethane phase containing the amino sugar derivatives were dried under nitrogen. Amino sugars were analyzed on the same GC-MS using similar conditions as PLFA analysis. The oven temperature increased from $120{ }^{\circ} \mathrm{C}$ (initial hold time $1 \mathrm{~min}$ ) to $270{ }^{\circ} \mathrm{C}$ at a rate of $10{ }^{\circ} \mathrm{C} \mathrm{min}{ }^{-1}$ with final hold at $270{ }^{\circ} \mathrm{C}$ for $5.5 \mathrm{~min}$. Quantification was achieved by comparing with surrogate standards to account for compound loss during extraction procedures. External quantification standards were used to normalize the response factor for different amino sugars separately.

Amino sugars include glucosamine, galactosamine, mannosamine, and muramic acid. Glucosamine is more abundant in fungal than bacterial cell walls while muramic acid is considered to be specific to bacteria (Guggenberger et al., 1999). Galactosamine and mannosamine are ubiquitous. The ratio of glucosamine to muramic acid (GlcN/MurA) indicates the ratio of fungi- versus bacteria-derived residues (Liang et al., 2015). A list of analyzed biomarkers, ratios and their meanings are given in Table S1.

\subsection{Statistical analysis}

All statistical analyses were conducted using $\mathrm{R}$ 3.4.3 (R Development Core Team 2009). Biomarker concentrations were normalized to SOC contents. Differences in biomarker concentrations or soil properties among vegetation types and between soil layers were analyzed by nonparametric tests (Kruskal-Wallis $\mathrm{H}$ and Wilcoxon test, respectively) due to non-normal distribution of data. As vegetation types coincide with soil types in this study, differences among vegetation types may be attributed to influences by vegetation and/or soil properties. The relationship of biomarker concentrations and ratios with environmental parameters was analyzed by a two-tailed Spearman correlation test. Due to the strong correlation between $\mathrm{Fe}$ and $\mathrm{Al}$ $(p<0.01)$, only $\mathrm{Al}$ is presented in this work. Differences or correlations were considered to be significant at a level of $p<0.05$.

Linear mixed effect models were used to determine the relative importance of different environmental variables in explaining the concentration and composition variance of the target microbial components in the studied grassland soils (Chen et al., 2015) using the "nlme" function in the R library. To facilitate interpretation and reduce collinearity, explanatory variables were classified into five groups: (1) climate (mainly represented by aridity index); (2) plant (aboveground biomass and species richness); (3) soil $\mathrm{pH}$; (4) soil macronutrients (SOC, $\mathrm{N}$ and $\mathrm{P}$ ); and (5) soil minerals ( $\mathrm{Ca}, \mathrm{Al}$ and soil texture). A principal component analysis (PCA) was performed for the groups containing more than one variable using the Kaise-Meyer-Olkin (KMO) and Bartlett's Spherical (BS) tests for feasibility analysis. The KMO results were $\geq 0.5$ except for minerals in the topsoil $(\mathrm{KMO}=0.42$ ) and the BS test results were significant $(p<0.05)$ except for minerals in the subsoil $(p<0.1)$, indicating that the PCA analysis was applicable to our data (Table S2). Hence, the first principal component (PC 1) was used in the subsequent linear mixed effect model analysis to represent the corresponding variables (explaining $>50 \%$ of variance in all cases; Table S3). In this analysis, aridity index, soil $\mathrm{pH}, \mathrm{PC} 1$ of soil macronutrients, soil minerals and plant properties were treated as fixed factors, and vegetation type was treated as a random grouping factor. When soil depth was used as a fixed factor in the model combining both soil depths, soil depth showed a significant effect on the concentration variance of most biomarkers, including IPL brGDGTs, CL iGDGTs, CL brGDGTs, bacterial PLFAs, Fungal PLFAs and muramic acid (Fig. S4). 
This result implied significant differences in the spatial distribution of these biomarkers in the top- versus subsoils. Therefore, the top- and subsoils were analyzed separately in our study. Finally, multivariable linear regression analysis was used to confirm the results of the linear mixed effect model. Both the model and effects of different variables were considered to be significant at a level of $p<0.05$.

\section{Results}

\subsection{Plant and soil bulk properties}

In the studied grasslands, plant aboveground biomass and species richness did not differ between the meadow and typical steppes $(p>0.05)$ and were on average $\sim 70 \%$ and $50 \%$ lower in the desert steppe than the other two vegetation types, respectively $(p<0.05$; Fig. 1d-e). The topsoil showed an increasing $\mathrm{pH}$ and decreasing contents of SOC, $\mathrm{N}$ and reactive $\mathrm{Al}$ with increasing aridity in the order of meadow steppe-typical steppe-desert steppe $(p<0.05)$ while contents of $\mathrm{P}$, Ca and clay + silt did not vary (Fig. 1f-1). By comparison, the subsoil had similar chemical properties under all vegetation types except for a lower $\mathrm{pH}$ under meadow steppes $(8.8 \pm 0.2)$ than desert steppes (9.4 $\pm 0.1 ; p<0.05$; Fig. 1f). Compared with the topsoil, subsoils showed variable $\mathrm{pH}$ and SOC, $\mathrm{N}$ and $\mathrm{P}$ contents under different vegetation types but had higher $\mathrm{Ca}(0.7 \pm 0.2 \%$ in topsoil and $2.5 \pm 0.3 \%$ in subsoil) and clay + silt contents $(20.8 \pm 2.0 \%$ in topsoil and $39.0 \pm 2.2 \%$ in subsoil) under all vegetation types $(p<0.05)$.

\subsection{Composition and abundance of biomarkers}

IPL-derived GDGTs (including iGDGTs and brGDGTs) had comparable SOC-normalized concentrations $\left(22.1 \pm 2.0 \mu \mathrm{g} \mathrm{g}^{-1}\right.$ SOC for IPL GDGTs, $18.7 \pm 1.8 \mu \mathrm{g} \mathrm{g}^{-1}$ SOC for IPL iGDGTs and $3.4 \pm 0.4 \mu \mathrm{g} \mathrm{g}^{-1}$ SOC for IPL brGDGTs) in the top- and subsoil among all vegetation types ( $p>0.05$; Fig. 2a-c). Compared with subsoils, the topsoil had higher concentrations of IPL-derived GDGTs under meadow steppes and typical steppes $(p<0.05)$. Similar to previous studies (Xie et al., 2012; Yang et al., 2014), IPL-iGDGTs $\left(18.7 \pm 1.8 \mu \mathrm{g} \mathrm{g}^{-1}\right.$ SOC) dominated over IPL-brGDGTs $\left(3.4 \pm 0.4 \mu \mathrm{g} \mathrm{g}^{-1} \mathrm{SOC}\right)$, resulting in high i/br ratios (up to 20; Fig. 2c) in alkaline and dry soil environments. The IPL i/br ratio was comparable between the top- and subsoils $(p>0.05)$ and lowest under meadow steppes at both depths $(p<0.05)$. By comparison, CL-derived iGDGTs (21.4 $\pm 1.7 \mu \mathrm{g} \mathrm{g}^{-1}$ SOC) and brGDGTs $\left(45.8 \pm 2.6 \mu \mathrm{g} \mathrm{g}^{-1} \mathrm{SOC}\right)$ had variable concentrations among vegetation types (Fig. 2d-e), resulting in similar concentrations of total CL GDGTs among vegetation types and between soil depths $(p>0.05$; Fig. $2 \mathrm{f})$. The i/br ratios of CL were higher in the top- $(0.81 \pm 0.10)$ than subsoils $(0.30 \pm 0.04)$ and lowest under meadow steppes $(0.51 \pm 0.12$ in topsoil and $0.16 \pm 0.03$ in subsoil) at both depths $(p<0.05)$. The GDGT-0/crenarchaeol ratio was well below 2 for both CL and IPL in our study and was lower in the sub- $0.07 \pm 0.01$ for CL and $0.06 \pm 0.05$ for IPL) than topsoil $(0.47 \pm 0.05$ for CL and $0.11 \pm 0.01$ for IPL; Fig. S5), consistent with the fact that anoxic conditions are not prevalent in arid and semiarid regions.

Soil PLFAs had comparable SOC-normalized concentrations $\left(0.10 \pm 0.01 \mathrm{mg} \mathrm{g}^{-1}\right.$ SOC for fungal PLFAs, $0.49 \pm 0.03 \mathrm{mg} \mathrm{g}^{-1}$ SOC for bacterial PLFAs and $0.78 \pm 0.05 \mathrm{mg} \mathrm{g}^{-1}$ SOC for PLFAs; Fig. 2g-i) in the topsoil among vegetation types ( $p>0.05$; Liu et al., 2020). In the subsoil, fungal and total PLFAs were most abundant and variant under meadow steppes $(p<0.05)$. Compared with the topsoil, subsoils had higher concentrations of fungal PLFAs under meadow steppes and typical steppes but lower concentrations of total PLFAs under desert steppes $(p<0.05)$. The F/B and G + /G- ratios were lower in the topthan subsoils of meadow steppes and typical steppes ( $p<0.05$; Fig. $2 \mathrm{i}$ and S5). The $\mathrm{F} / \mathrm{B}$ ratios were comparable among vegetation types $(p>0.05)$ and $\mathrm{G}+/ \mathrm{G}-$ ratios were higher in the topsoil of typical steppes than desert steppes ( $p<0.05$; Fig. S6).

Glucosamine and total amino sugars had similar concentrations $\left(28.1 \pm 1.0 \mathrm{mg} \mathrm{g}^{-1} \mathrm{SOC}\right.$ for glucosamine; $55.1 \pm 1.6 \mathrm{mg} \mathrm{g}^{-1} \mathrm{SOC}$ for amino sugars) among vegetation types and between soil depths $(p>0.05)$, while muramic acid showed variable concentrations $\left(6.5 \pm 0.3 \mathrm{mg} \mathrm{g}^{-1}\right.$ SOC; Fig. $\left.2 \mathrm{j}-1\right)$. The GlcN/MurA ratio was higher in the topsoil of meadow steppe $(6.2 \pm 0.3)$ than other vegetation types (4.5 $\pm 0.3 ; p<0.05)$ and in the top- $(6.2 \pm 0.3)$ than subsoils (3.7 \pm 0.6$)$ of meadow steppes $(p<0.05$; Fig. 21$)$.

PLFAs (including fungal and bacterial subgroups) were not correlated with any other biomarkers in terms of SOC-normalized concentration at either depth ( $p>0.05 ;|\mathrm{r}|<0.3$; Fig. S7a-b). IPL-derived iGDGTs (accounting for $>79 \%$ of total IPL-derived GDGTs) and total GDGTs were positively correlated with CL iGDGTs in the topsoil ( $p<0.05 ; \mathrm{r}=0.49$ and 0.38 , respectively) and with all CL GDGT components in the subsoil ( $p<0.05 ; \mathrm{r}>0.37$; Fig. S7b). CL brGDGTs had a strong positive correlation with glucosamine and total amino sugars in the topsoil ( $p<0.05 ; \mathrm{r}=0.59$ and 0.43 , respectively), while CL and IPL-derived iGDGTs had negative correlations with glucosamine $(p<0.05 ;|\mathrm{r}|<0.38)$. IPL-derived brGDGTs and muramic acid were also positively correlated in the subsoil ( $p<0.05 ; \mathrm{r}=0.38$ ). The ratios of CL and IPL i/br and F/B were positively correlated with each other in the topsoil ( $p<0.05$; $r>0.57$; Fig. S7c) but not in the subsoil ( $p>0.05$; $\mathrm{r}$ : $-0.29 \sim 0.45$ ). The IPL/CL ratios for brGDGTs, iGDGTs and total GDGTs were positively correlated with each other $(p<0.05 ; \mathrm{r}>0.47)$ and positively correlated with ratios of IPLderived GDGTs/amino sugars in both top- and subsoils $(p<0.05$; $r=0.35 \sim 0.83$; Fig. S7c-d), indicating similar variation patterns for the biomass-to-necromass ratios of GDGT-producing microbes in the soil.

\subsection{Microbial biomass versus necromass components in soils}

GDGTs derived from living bacteria and archaea (i.e., IPL-derived) represented a different fraction of total GDGTs derived from both biomass and necromass (i.e., CL), indicated by a significantly lower \%IPL for brGDGTs $(7.2 \pm 0.8 \%)$ than iGDGTs $(46.0 \pm 1.9 \%$; $p<0.05$; Fig. 3a-b). Both brGDGTs and iGDGTs showed similar \%IPL values among different vegetation types $(p>0.05)$ but the values were lower in the sub- than topsoil of meadow steppes and typical steppes for brGDGTs and higher in the sub- than topsoil of meadow steppes and desert steppes for iGDGTs $(p<0.05)$. Consequently, the IPL/CL ratios (and similarly \%IPL) were higher in the top- than subsoils of the studied grasslands (particularly in the meadow and typical steppes) for brGDGTs but lower in the top- than subsoil of desert steppes for iGDGTs ( $p<0.05$; Fig. 3c-d). By comparison, the ratios of PLFAs/amino sugars and IPL-derived GDGTs/amino sugars showed no significant difference between soil depths or among vegetation types ( $p>0.05$; Fig. 3e-f), indicating relatively constant ratios of vast microbial biomass to necromass among vegetation types in the studied grasslands.

\subsection{Relationships between environmental parameters and biomarker concentrations}

The relationship between the abundance of microbial components and various environmental parameters was assessed for the top- and subsoils separately (Table 1). Based on linear mixed effect models, only concentrations of IPL-derived brGDGTs, CL iGDGTs, muramic acid and glucosamine were significantly related to the selected environmental variables in the topsoil $(p<0.05$; confirmed by multivariable linear regression), which totally explained $38 \%-46 \%$ of the concentration variance for the respective biomarkers (Fig. 4a). Climate (i.e., aridity index) showed a significant relation to the concentration of IPL-derived brGDGTs, CL iGDGTs and glucosamine $(p<0.05)$, and also best explained the concentration variance of most biomarkers (except CL GDGTs, bacterial PLFAs and muramic acid) in the topsoil albeit with 


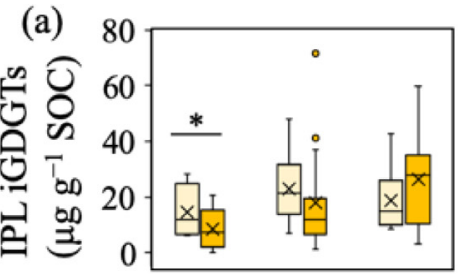

(d)

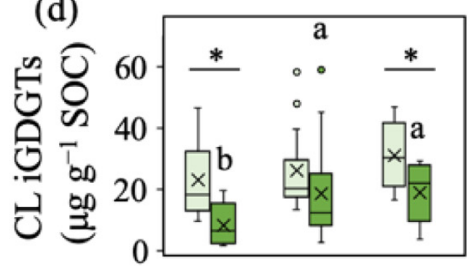

(g)

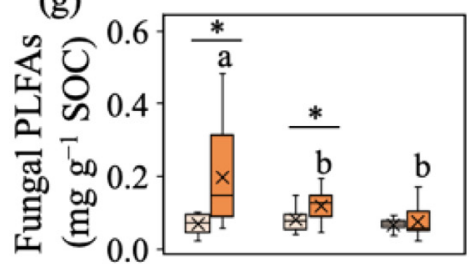

(j)

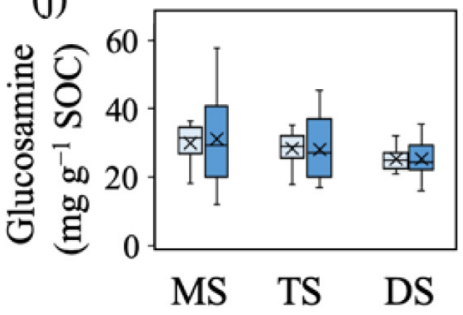

(b)

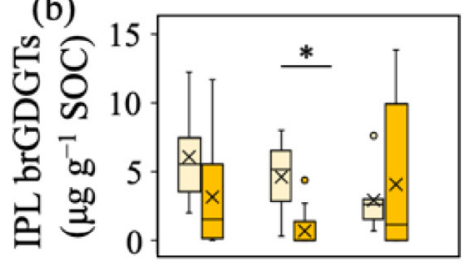

(e)

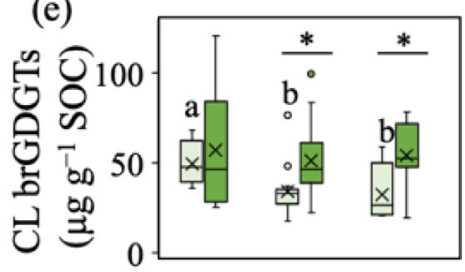

(h)

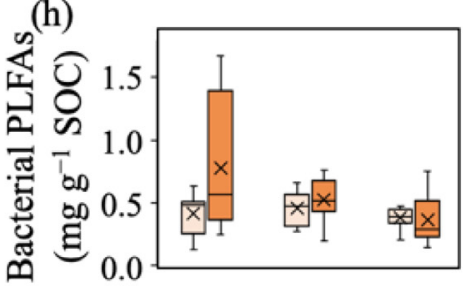

(k)

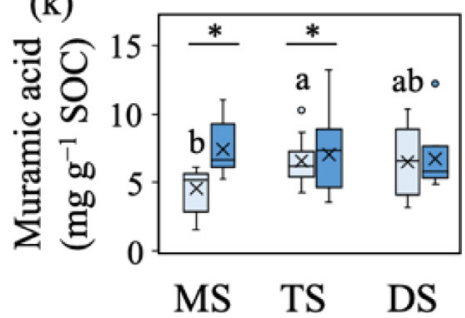

(c)

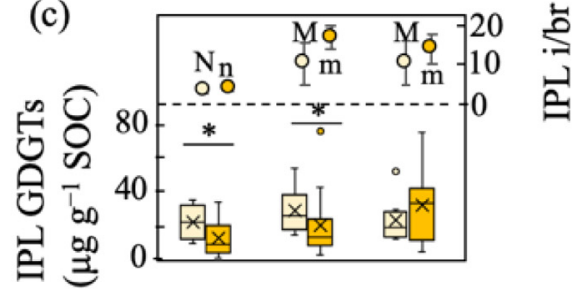

(f)
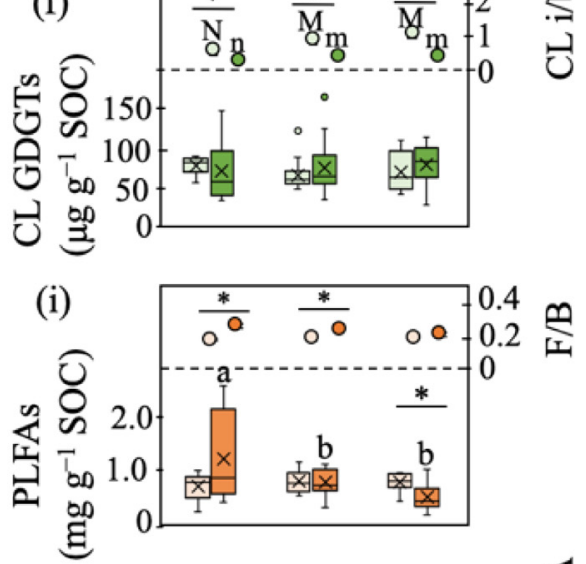

(1)

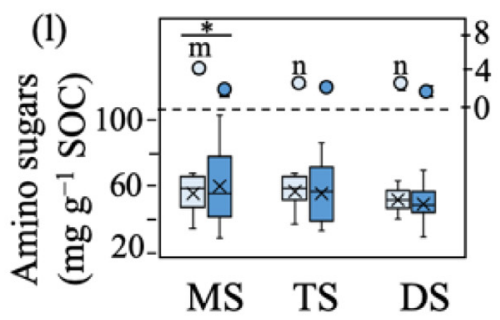

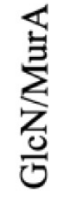

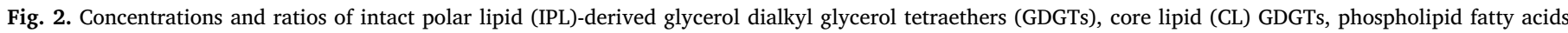

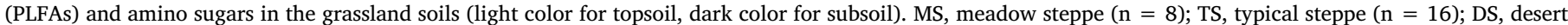

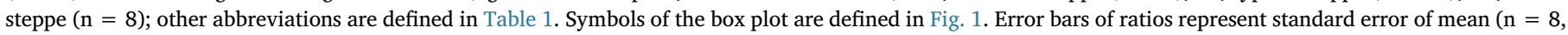

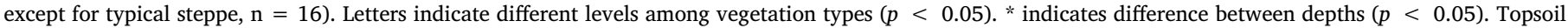
PLFAs are reported in Liu et al. (2020).

non-significant effect ( $p>0.05)$. By comparison, soil macronutrients had a significant and strongest influence on muramic acid concentrations in the topsoil $(p<0.05)$. In the subsoil, most of microbial components (except IPL-derived and CL brGDGTs, CL GDGTs and muramic acid) were significantly affected by the selected environmental variables $(p<0.05)$, which explained $34 \%-46 \%$ of the concentration variance of the respective biomarkers (Fig. 4b). Other than climate, soil $\mathrm{pH}$, macronutrients and minerals also had a significant effect on the concentration of most biomarkers $(p<0.05)$. Similar to the topsoil, only soil macronutrients explained the concentration variance of muramic acid distribution in the subsoil $(p<0.05$; Table 1$)$.

\section{Discussion}

\subsection{Amino sugar distribution in the Mongolian soils}

Amino sugars have a lower concentration in this study (which is based on the Inner Mongolian grasslands, sampled in 2015; $55.1 \pm 1.6 \mathrm{mg} \mathrm{g}^{-1}$ SOC; $\mathrm{n}=32$ ), compared with our previous study on a wider span of Chinese-Mongolian transects (sampled in 2011-2012; $77.7 \pm 2.7 \mathrm{mg} \mathrm{g}^{-1}$ SOC for grassland sites; $\mathrm{n}=80$; $p<0.05$; Ma et al., 2018). Given the much lower aboveground biomass $\left(98.6 \pm 10.5 \mathrm{~g} \mathrm{~m}^{-2}\right.$ ) and SOC contents for sites in this study $(1.49 \pm 0.18 \% ; \mathrm{n}=32)$ relative to the previous ones (165.4 $\pm 9.8 \mathrm{~g} \mathrm{~m}^{-2}$ and $2.00 \pm 0.13 \%$, respectively; $\mathrm{n}=80$; $p<0.05$; Ma et al., 2018), we deduce that the sampling sites in this study, although selected to avoid human disturbances, could be affected by grazing. It is also reported that the average grazing capacity (3.95 sheep $\mathrm{ha}^{-1}$ ) and overgrazing rate (275.8\%) are significantly higher on Inner Mongolian than on Mongolian grasslands (2.92 sheep ha ${ }^{-1}$ and 180.5\%; Wu, 2017). Grazing not only reduces plant biomass and hence inputs into the soil but is also reported to decrease soil permeability and microbial activity (Xiong et al., 2016; Kusakabe et al., 2018; Zhang et al., 2020). Grazing may also negatively affect the presence of soil fungi (especially mycorrhizal fungi; Olsson et al., 2010). Hence, sites influenced by grazing may inhibit the accumulation of microbial necromass (especially glucosamine; Fig. 21). Differences in amino sugar concentrations between these two studies are hence most likely explained by the different influences of grazing on the sampling sites. This result implies that improved grazing management (e.g., rotational grazing) may increase soil microbial carbon sequestration in the temperate grasslands. It is therefore critical to consider grazing effect in studies or models of carbon sequestration.

Despite a lower abundance, amino sugars show similar spatial distribution patterns in the Inner Mongolian grasslands of this study as across the Chinese-Mongolian transect (Fig. S8; including desert sites) in Ma et al. (2018). In particular, aridity index rather than soil texture (clay + silt content) exhibits a positive correlation with amino sugar concentrations in the coarse-textured grassland topsoil, confirming that microbial necromass accumulation is enhanced with increasing 

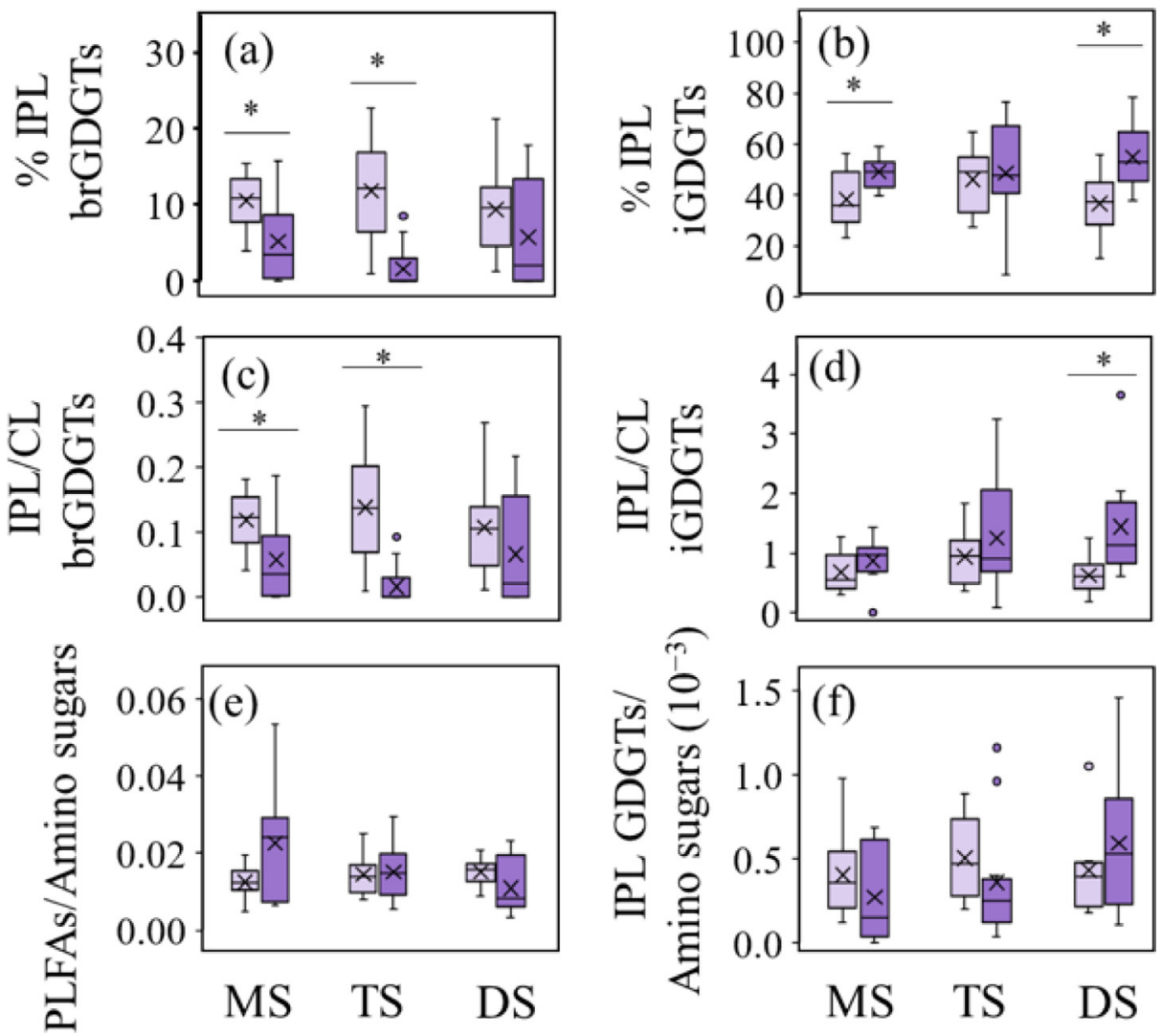

Fig. 3. Ratios of microbial biomass versus necromass components in the soil (light color for topsoil, dark color for subsoil). MS, meadow steppe ( $\mathrm{n}=8)$; TS, typical steppe $(\mathrm{n}=16)$; DS, desert steppe ( $\mathrm{n}=8)$; \%IPL, percentage of IPL-derived GDGTs in total GDGTs (CL and IPL-derived); other abbreviations are defined in Table 1 . Symbols of the box plot are defined in Fig. 1. Letters indicate different levels among vegetation types $(p<0.05)$. * indicates difference between depths $(p<0.05)$. humidity in the semiarid grasslands (Ma et al., 2018). In the Mongolian grasslands, precipitation is the primary factor limiting plant primary productivity and soil microbial activity (Bai et al., 2004; Chen et al., 2015). Generally, as MAP increases, microbial growth (Chen et al., 2015; Lange et al., 2015) and necromass accumulation (Ma et al., 2018) increase together with plant biomass and diversity. Cao et al. (2019) also reported that energy and nutrients from soil organic matter decomposition are preferentially allocated to the soil microbial catabolism in the desert steppe of Inner Mongolia versus microbial anabolism (i.e., growth and reproduction) in humid meadow steppe.

\subsection{Links between microbial biomass and necromass components in the} Mongolian soils

Microbial biomass and necromass components show weak relationships in the topsoil such that only the concentration of CL iGDGTs (necromass biomarker) shows positive correlations with IPL iGDGTs (biomass biomarker; Fig. S7a). This weak correlation, along with the high abundance of bacterial biomass relative to necromass in the topsoil (indicated by higher ratios of IPL/CL brGDGT; Fig. 3c), suggests that bacterial necromass preservation or turnover plays a more important

Table 1

Spearman correlation coefficients (r) of soil organic carbon (SOC)-normalized concentrations of biomarkers with environmental variables in the grassland soils ( $\mathrm{n}=32 ; p<0.05$ ). Color shade corresponds to the value of $\mathrm{r}$ (red for negative and blue for positive correlations).

\begin{tabular}{|c|c|c|c|c|c|c|c|c|c|c|c|c|c|c|c|c|c|c|c|c|c|c|c|}
\hline & \multicolumn{12}{|c|}{ Topsoil } & \multicolumn{11}{|c|}{ Subsoil } \\
\hline & MAP & MAT & $\begin{array}{c}\text { Aridity } \\
\text { index }\end{array}$ & AGB & SR & $\mathrm{pH}$ & SOC & $\mathrm{N}$ & $\mathrm{P}$ & $\mathrm{Ca}$ & $\mathrm{Al}$ & $\begin{array}{c}\text { Clay+ } \\
\text { silt }\end{array}$ & MAP & MAT & $\begin{array}{c}\text { Aridity } \\
\text { index }\end{array}$ & AGB & SR & $\mathrm{pH}$ & SOC & $\mathrm{N}$ & $\mathrm{P}$ & $\mathrm{Ca}$ & $\mathrm{Al} \underset{\text { silt }}{\text { Clay+ }}$ \\
\hline Amino sugars & 0.39 & -0.52 & 0.41 & ns & ns & -0.36 & ns & ns & ns & ns & 0.49 & ns & ns & -0.36 & $\mathrm{~ns}$ & ns & ns & ns & ns & ns & -0.43 & -0.68 & ns -0.44 \\
\hline Glucosamine & 0.53 & -0.7 & 0.6 & 0.4 & 0.52 & -0.43 & 0.42 & 0.39 & ns & ns & 0.62 & ns & ns & -0.39 & ns & ns & ns & ns & ns & ns & ns & -0.72 & $\mathrm{~ns}-0.47$ \\
\hline Muramic acid & ns & ns & ns & ns & ns & ns & -0.4 & -0.38 & -0.55 & -0.5 & ns & -0.38 & ns & ns & ns & ns & ns & $\underline{\text { ns }}$ & -0.67 & -0.61 & -0.54 & -0.42 & ns \\
\hline PLFAs & $\mathrm{ns}$ & $\mathrm{ns}$ & ns & ns & ns & $\mathrm{ns}$ & ns & ns & ns & ns & $\mathrm{ns}$ & $\mathrm{ns}$ & 0.52 & -0.42 & 0.5 & 0.38 & 0.45 & ns & ns & $\mathrm{ns}$ & ns & ns & ns \\
\hline Fungal PLFAs & ns & ns & ns & ns & ns & ns & ns & ns & ns & ns & ns & ns & 0.48 & -0.38 & 0.47 & ns & 0.45 & ns & ns & ns & ns & ns & ns \\
\hline Bacterial PLFAs & ns & ns & ns & ns & ns & ns & ns & ns & ns & ns & ns & ns & 0.4 & ns & ns & ns & ns & ns & $\underline{\mathrm{ns}}$ & ns & ns & ns & ns \\
\hline CL GDGTs & ns & ns & ns & ns & ns & $\mathrm{ns}$ & ns & ns & ns & ns & ns & $\mathrm{ns}$ & -0.42 & ns & -0.42 & ns & ns & 0.47 & $\mathrm{~ns}$ & ns & ns & ns & $\mathrm{ns}$ \\
\hline CL brGDGTs & 0.43 & -0.56 & 0.56 & ns & $\mathrm{ns}$ & $\mathrm{ns}$ & 0.47 & 0.43 & ns & ns & ns & ns & ns & ns & ns & ns & ns & 0.36 & -0.35 & ns & ns & ns & ns \\
\hline CL iGDGTs & -0.52 & 0.52 & -0.56 & -0.5 & -0.55 & 0.44 & -0.4 & -0.36 & $\underline{\text { ns }}$ & ns & -0.43 & ns & -0.7 & 0.54 & -0.67 & -0.54 & -0.44 & 0.65 & $\underline{\mathrm{ns}}$ & ns & ns & 0.4 & ns \\
\hline IPL GDGTs & $\mathrm{ns}$ & ns & ns & $\mathrm{ns}$ & ns & $\mathrm{ns}$ & ns & ns & ns & ns & ns & $\mathrm{ns}$ & -0.41 & $\mathrm{~ns}$ & -0.41 & ns & -0.49 & 0.4 & ns & ns & ns & ns & ns \\
\hline IPL brGDGTs & 0.41 & -0.51 & 0.51 & ns & 0.36 & ns & 0.39 & ns & ns & ns & ns & ns & ns & ns & ns & ns & ns & ns & ns & ns & ns & ns & ns \\
\hline IPL iGDGTs & -0.37 & ns & ns & ns & -0.36 & ns & ns & ns & ns & ns & -0.4 & ns & -0.46 & ns & -0.45 & ns & -0.52 & 0.42 & ns & ns & ns & 0.36 & ns \\
\hline
\end{tabular}

PLFAs, phospholipid fatty acids; GDGTs, glycerol dialkyl glycerol tetraethers; IPL, intact polar lipid; CL, core lipid; brGDGTs, branched GDGTs; iGDGTs, isoprenoid GDGTs; MAP, mean annual precipitation; MAT, mean annual temperature; AGB, aboveground biomass; SR, plant species richness; SOC, soil organic carbon; N, soil nitrogen; P, soil phosphorus; Ca, dithionite-extractable calcium; Al, dithionite-extractable aluminum; ns, not significant. 


\section{(a) $0-10 \mathrm{~cm}$}

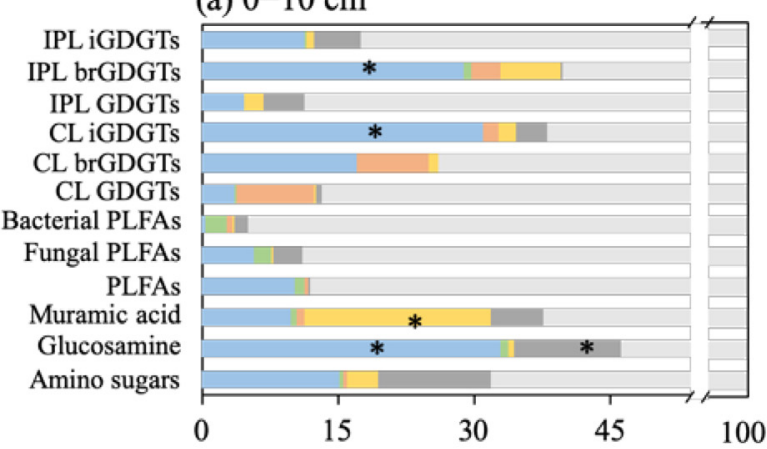

(b) $30-50 \mathrm{~cm}$

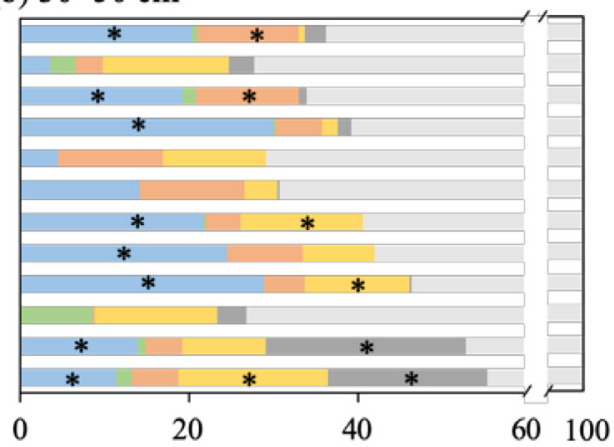

Variation $(\%)$

\section{$\square$ Aridity index $\square$ Plant $\square$ Soil pH $\square$ Soil macronutrients $\square$ Minerals $\square$ Unexplained}

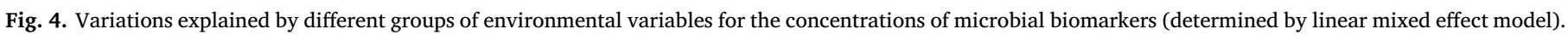

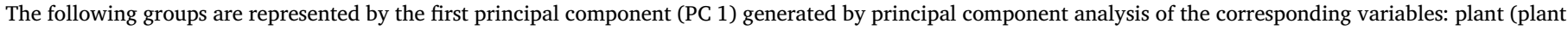

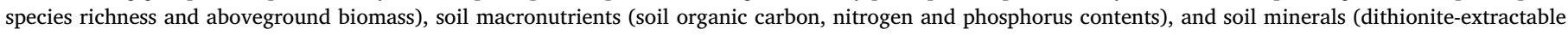
calcium, aluminum and clay + silt content). *indicates significant influence $(p<0.05)$. Abbreviations are defined in Fig. 2.

role in regulating its abundance in the topsoil (Liang and Balser, 2011). Somewhat in line with this postulation, microbial necromass components, including total amino sugars, glucosamine and CL brGDGTs, are positively correlated with each other in the topsoil (Fig. S7a) and have similar relationships with environmental factors (Table 1). These relationships further indicate that these microbial necromass components share similar preservation mechanisms rather than common producers (since fungi and bacteria are considered to be the main contributor of glucosamine and brGDGTs, respectively; Amelung et al., 2001; Weijers et al., 2006a) in the topsoil.

In the subsoil, the concentration of CL iGDGTs also shows positive correlations with IPL iGDGTs, suggesting strong links between microbial biomass and necromass carbon components derived from archaea at both soil depths. Besides, muramic acid is also positively correlated with IPL-derived brGDGTs in the subsoil (Fig. S7b). As brGDGTs and muramic acid are derived from bacterial membranes and cell walls, respectively (Zhang and Amelung, 1996; Weijers et al., 2006b), their correlations indicate a close link between bacterial necromass and biomass in the subsoil (Gocke et al., 2017). Together with the high abundance of bacterial necromass relative to biomass in the subsoil (indicated by low fraction of IPL relative to CL brGDGTs; Fig. 3a), these results indicate that bacterial necromass is well preserved in the subsoil (further discussed in Section 4.4). Hence, it is predicted that an increase in microbial biomass input (e.g., via increased rhizodeposition) may enhance bacterial carbon sequestration in the subsoil of these grasslands.

\subsection{Contrasting drivers for microbial component distribution in the top- versus subsoils}

The distribution of microbial components is affected by different environmental factors in the top- versus subsoils. Aridity index best explains the concentration variance of most biomarkers (except CL GDGTs, bacterial PLFAs and muramic acid) in the topsoil (Fig. 4a). This result is consistent with previous reports that climate (i.e., aridity) is the primary predictor for the abundance of microbial-derived carbon component in arid and semiarid grasslands (Bardgett et al., 2001; Chen et al., 2015; Ma et al., 2018) because primary productivity and microbial activity are both controlled by water availability in this region (Bai et al., 2004; Chen et al., 2015). In contrast, in Californian semiarid grasslands, soil microbial communities are generally highly tolerant to desiccation (Barnard et al. 2013). The discrepancy may be associated with microbial adaptation to different climates in these two regions, where California grasslands have hot, dry summers and higher MAP (310-950 mm) as opposed to hot, wet summers and lower MAP (173-415 mm) in the Inner Mongolian grasslands. On the other hand, edaphic properties (i.e., $\mathrm{pH}$ and macronutrients) explain a significant fraction of the abundance variance of most biomarkers (except muramic acid) in the subsoil (Fig. 4b). As subsoils of the studied grasslands have lower contents of SOC, N and P than the topsoil (Fig. 1g-i), the substrate-deprived microbes in the subsoil are likely more sensitive to the variation of macronutrients in terms of both biomass production and residue preservation (Baisden et al., 2002; Fierer et al., 2003b). Soil pH is also higher in the sub- than topsoil (Fig. 1f) and microbial components seem to be more sensitive to $\mathrm{pH}$ variations in the more alkaline soils (Beman et al., 2011). This effect is particularly obvious for iGDGTs in the subsoil (Table 1), potentially linked to archaea-mediated ammonium oxidation process that is $\mathrm{pH}$ sensitive in alkaline soils (Weijers et al., 2006a; Beman et al., 2011). The above findings fall in line with our first hypothesis that edaphic properties have a stronger influence on the abundance of microbial carbon components in subsoil and are also consistent with previous reports that resource (i.e., carbon, $\mathrm{N}$ and $\mathrm{P}$ ) availability is the primary control on microbial biomass and metabolic diversity in temperate grassland subsoils (Fierer et al., 2003b; Liang et al., 2019).

\subsection{Elevated preservation of bacterial necromass in the subsoil}

Interestingly, the IPL/CL ratio (and similarly \%IPL) for brGDGTs is lower in the sub- than topsoil of the studied grasslands (Fig. 3a and 3c). As IPL is only found in living microbes, including viable-but-nonculturable dwarf cells (Harvey et al., 1986; White et al., 1979), the above result indicates a higher abundance of bacterial necromass relative to biomass in the subsoil. As microbial activity and community turnover are known to decrease with soil depth due to substrate constraints (Fierer et al., 2003a; Liang et al., 2019), increased preservation of bacterial residues likely explains the higher abundance of bacterial necromass relative to biomass in the subsoil, partly consistent with our second hypothesis.

At least two factors may contribute to the enhanced preservation of bacterial necromass in the subsoil. First, fine-sized particles (clay + silt) are more abundant in the sub- than topsoil (Fig. 11), which potentially provide physical protection for microbial necromass (Six et al., 2006; Ma et al., 2018) that tends to accumulate in mineral- 
associated soil fractions (Kögel-Knabner et al., 2008; Sollins et al., 2009). However, as the Mongolian soils are coarse-textured in general (Demoux et al., 2009), the effect of mineral protection is not obvious for our samples (Table 1). Alternatively, Ca is known to play a vital role in stabilizing SOC in alkaline soils via Ca bridging (Rowley et al., 2018). $\mathrm{Ca}$ is positively correlated with the concentration of CL brGDGTs when both soil layers are considered $(r=0.30, p=0.02, \mathrm{n}=64)$. Given the higher abundance of $\mathrm{Ca}$ in the subsoil (Fig. $1 \mathrm{j}$ ), Ca seems to play a key role in preserving bacterial necromass in the subsoil. Second, as mentioned previously, surface soils $(<20 \mathrm{~cm})$ harbouring more than $70 \%$ of plant roots of the studied grasslands (Ma et al., 2008) may be under higher $\mathrm{N}$ limitation due to limited supply of inorganic $\mathrm{N}$ via mineralization and elevated plant-microbe competition for $\mathrm{N}$ at high-productivity sites (Zhang et al., 2016). Severe N competition may induce elevated decomposition or recycling of microbial residues (such as amino sugars) that contain a relatively high level of $\mathrm{N}$ compared to plant-derived organic matter (Jia et al., 2017; Cui et al., 2020). Therefore, we speculated that the lower $\mathrm{N}$ limitation in the sub- than topsoil resulted in the better preservation of bacterial necromass in the subsoil of typical and desert steppes.

In contrast to bacterial components, the IPL/CL ratio (and \%IPL) for iGDGTs is higher in the sub- than topsoil of the meadow steppes and desert steppes (Fig. 3b and d), indicating a lower abundance of archaeal necromass relative to biomass in the subsoil. In addition, the $\mathrm{i} / \mathrm{br}$ ratio is comparable between depths for IPL (Fig. 2c) but higher in the topthan subsoils for CL (Fig. 2f). This implies that compared to bacterial residues (i.e., brGDGTs), archaeal residues (i.e., iGDGTs) have a lower relative abundance or accumulation efficiency per unit of biomass in the subsoil. This contrast may be linked to the different ecological niche or growth strategies for bacteria and archaea in the grasslands (Schouten et al., 2013). Future increases in the precipitation of this region (Ni and Zhang, 2000) may increase the role of bacteria in microbial carbon sequestration in the subsoil.

\section{Conclusions}

In summary, employing different biomarkers derived from fungi, bacteria and archaea, this study presents the first large-scale investigation on the links between microbial biomass and necromass components in the top- versus subsoils across the temperate grasslands of China along an aridity gradient. The majority of microbial necromass components (except CL iGDGTs) show little correlation with the markers of their corresponding living producers in the topsoil, suggesting that microbial necromass abundance is more related to its preservation rather than community production in the topsoil. By comparison, bacterial necromass components are better preserved relative to biomass in the subsoil, possibly due to stronger association of microbial necromass with $\mathrm{Ca}$ and/or reduced $\mathrm{N}$ competition with plants at depth. As a result, there is a closer link between the abundance of bacterial necromass (including CL brGDGTs and muramic acid) and biomass in the subsoil. Furthermore, using linear mixed effect model analyses, we find that while aridity index best explains the concentration variance of most biomarkers in the topsoil, edaphic properties (i.e., $\mathrm{pH}$ and macronutrients) also contribute significantly to the concentration variance for most biomarkers in the subsoil. These results collectively suggest that microbial carbon displays distinct preservation and distribution patterns at different depths of the studied grasslands, providing new information to understand microbial-mediated SOC accumulation and stability mechanisms in a changing environment. Given the better preservation of bacterial necromass carbon at depth and its strong link to biomass in terms of spatial distributions, potential increases in microbial (in particular, bacterial) biomass production under future climate and environmental changes (such as precipitation increases) may enhance microbial carbon sequestration in the deep soil in the Mongolian grasslands.

\section{Declaration of Competing Interest}

The authors declare that they have no known competing financial interests or personal relationships that could have appeared to influence the work reported in this paper.

\section{Acknowledgements}

This study was funded by the Chinese National Key Development Program for Basic Research (2017YFC0503902), the National Natural Science Foundation of China $(41773067,31971502,31988102)$ and the Chinese Academy of Sciences CAS Interdisciplinary Innovation Team (JCTD-2018-06). GDGT analyses were financially supported by the China Exchange Program of the Royal Netherlands Academy of Arts and Sciences (KNAW, Grant No. 530-6CDP17 to F. Peterse and X. Feng). The data are available from the tables, figures, and supplementary information of the paper. The authors have no conflict of interest to declare.

\section{Appendix A. Supplementary data}

Supplementary data to this article can be found online at https:// doi.org/10.1016/j.geoderma.2020.114623.

\section{References}

Albers, S.-V., Meyer, B.H., 2011. The archaeal cell envelope. Nat. Rev. Microbiol. 9 (6), 414-426.

Amelung, W., Kimble, J.M., Samson-Liebig, S., Follett, R.F., 2001. Restoration of microbial residues in soils of the Conservation Reserve Program. Soil Sci. Soc. Am. J. 65 (6), 1704-1709.

Bai, Y., Han, X., Wu, J., Chen, Z., Li, L., 2004. Ecosystem stability and compensatory effects in the Inner Mongolia grassland. Nature 431, 181-184.

Baisden, W.T., Amundson, R., Cook, A.C., Brenner, D.L., 2002. Turnover and storage of C and $\mathrm{N}$ in five density fractions from California annual grassland surface soils. Global Biogeochem. Cycles 16 (4), 1117.

Bardgett, R.D., Jones, A.C., Jones, D.L., Kemmitt, S.J., Cook, R., Hobbs, P.J., 2001. Soil microbial community patterns related to the history and intensity of grazing in submontane ecosystems. Soil Biol. Biochem. 33 (12-13), 1653-1664.

Bardgett, R.D., McAlister, E., 1999. The measurement of soil fungal: bacterial biomass ratios as an indicator of ecosystem self-regulation in temperate meadow grasslands. Biol. Fertil. Soils 29 (3), 282-290.

Barnard, R.L., Osborne, C.A., Firestone, M.K., 2013. Responses of soil bacterial and fungal communities to extreme desiccation and rewetting. ISME J. 7, 2229-2241.

Beman, J.M., Chow, C.-E., King, A.L., Feng, Y., Fuhrman, J.A., Andersson, A., Bates, N.R., Popp, B.N., Hutchins, D.A., 2011. Global declines in oceanic nitrification rates as a consequence of ocean acidification. Proc. Natl. Acad. Sci. 108 (1), 208-213.

Blaga, C.I., Reichart, G.-J., Heiri, O., Sinninghe Damsté, J.S., 2009. Tetraether membrane lipid distributions in water-column particulate matter and sediments: a study of 47 European lakes along a north-south transect. J. Paleolimnol. 41, 523-540.

Bligh, E.G., Dyer, W.J., 1959. A rapid method of total lipid extraction and purification. Can. J. Biochem. Physiol. 37, 911-917.

Cao, Y., Xu, L., Zhang, Z., Chen, Z., He, N., 2019. Soil microbial metabolic quotient in Inner Mongolian grasslands: patterns and influence factors. Chin. Geogr. Sci. 29 (6), 1001-1010.

Chen, D., Mi, J., Chu, P., Cheng, J., Zhang, L., Pan, Q., Xie, Y., Bai, Y., 2015. Patterns and drivers of soil microbial communities along a precipitation gradient on the Mongolian Plateau. Landsc. Ecol. 30, 1669-1682.

Cotrufo, M.F., Wallenstein, M.D., Boot, C.M., Denef, K., Paul, E, 2013. The Microbial Efficiency-Matrix Stabilization (MEMS) framework integrates plant litter decomposition with soil organic matter stabilization: do labile plant inputs form stable soil organic matter? Glob. Chang. Biol. 19, 988-995.

Cui, J., Zhu, Z., Xu, X., Liu, S., Jones, D.L., Kuzyakov, Y., Shibistova, O., Wu, J., Ge, T., 2020. Carbon and nitrogen recycling from microbial necromass to cope with C: N stoichiometric imbalance by priming. Soil Biol. Biochem. 142, 107720.

Dai, G., Ma, T., Zhu, S., Liu, Z., Chen, D., Bai, Y., Chen, L., He, J.-S., Zhu, J., Zhang, Y., Lü, X., Wang, X., Han, X., Feng, X., 2018. Large-scale distribution of molecular components in chinese grassland soils: the influence of input and decomposition processes. J. Geophys. Res.: Biogeosci. 123 (1), 239-255.

Demoux, A., Kröner, A., Liu, D., Badarch, G., 2009. Precambrian crystalline basement in southern Mongolia as revealed by SHRIMP zircon dating. Int. J. Earth Sci. 98 (6), 1365-1380.

Feng, X., Simpson, M.J., 2009. Temperature and substrate controls on microbial phospholipid fatty acid composition during incubation of grassland soils contrasting in organic matter quality. Soil Biol. Biochem. 41, 804-812.

Fierer, N., Schimel, J.P., Holden, P.A., 2003a. Variations in microbial community composition through two soil depth profiles. Soil Biol. Biochem. 35, 167-176. 
Fierer, N., Allen, A.S., Schimel, J.P., Holden, P.A., 2003b. Controls on microbial CO2 production: a comparison of surface and subsurface soil horizons. Glob. Chang. Biol. 9, 1322-1332.

Frostegård, A., Bååth, E., 1996. The use of phospholipid fatty acid analysis to estimate bacterial and fungal biomass in soil. Biol. Fertil. Soils 22, 59-65.

Glaser, B., Millar, N., Blum, H., 2006. Sequestration and turnover of bacterial- and fungalderived carbon in a temperate grassland soil under long-term elevated atmospheric pCO2. Glob. Chang. Biol. 12, 1521-1531.

Glaser, B., Turrión, M.A.-B., Alef, K., 2004. Amino sugars and muramic acid-biomarkers for soil microbial community structure analysis. Soil Biol. Biochem. 36, 399-407.

Gocke, M.I., Huguet, A., Derenne, S., Kolb, S., Dippold, M.A., Wiesenberg, G.L.B., 2017. Disentangling interactions between microbial communities and roots in deep subsoil. Sci. Total Environ. 575, 135-145.

Guckert, J.B., Antworth, C.P., Nichols, P.D., White, D.C., 1985. Phospholipid, ester-linked fatty acid profiles as reproducible assays for changes in prokaryotic community structure of estuarine sediments. FEMS Microbiol. Ecol. 31, 147-158.

Guerrant, G.O., Moss, C.W., 1984. Determination of monosaccharides as aldononitrile, Omethyloxime, alditol, and cyclitol acetate derivatives by gas chromatography. Anal. Chem. 56, 633-638.

Guggenberger, G., Frey, S.D., Six, J., Paustian, K., Elliott, E.T., 1999. Bacterial and fungal cell-wall residues in conventional and no-tillage agroecosystems. Soil Sci. Soc. Am. J. 63, 1188-1198.

Günther, F., Thiele, A., Gleixner, G., Xu, B., Yao, T., Schouten, S., 2014. Distribution of bacterial and archaeal ether lipids in soils and surface sediments of Tibetan lakes: Implications for GDGT-based proxies in saline high mountain lakes. Org. Geochem. 67, 19-30.

Harvey, H.R., Fallon, R.D., Patton, J.S., 1986. The effect of organic matter and oxygen on the degradation of bacterial membrane lipids in marine sediments. Geochim. Cosmochim. Acta 50, 795-804.

Huguet, C., Hopmans, E.C., Febo-Ayala, W., Thompson, D.H., Sinninghe Damsté, J.S., Schouten, S., 2006. An improved method to determine the absolute abundance of glycerol dibiphytanyl glycerol tetraether lipids. Org. Geochem. 37, 1036-1041.

IUSS Working Group WRB, 2015. World Reference Base for Soil Resources 2014, Update 2015. World Soil Resources Reports, No. 106. FAO, Rome.

Jia, J., Feng, X., He, J.-S., He, H., Lin, L., Liu, Z., 2017. Comparing microbial carbon sequestration and priming in the subsoil versus topsoil of a Qinghai-Tibetan alpine grassland. Soil Biol. Biochem. 104, 141-151.

Joergensen, R.G., 2018. Amino sugars as specific indices for fungal and bacterial residues in soil. Biol. Fertil. Soils 54, 559-568.

Kallenbach, C.M., Frey, S.D., Grandy, A.S., 2016. Direct evidence for microbial-derived soil organic matter formation and its ecophysiological controls. Nat. Commun. 7 , 13630.

Kandler, O., König, H., 1998. Cell wall polymers in Archaea Archaebacteria (Archaebacteria). Cell. Mol. Life Sci. 54, 305-308.

Kögel-Knabner, I., Guggenberger, G., Kleber, M., Kandeler, E., Kalbitz, K., Scheu, S., Eusterhues, K., Leinweber, P., 2008. Organo-mineral associations in temperate soils: Integrating biology, mineralogy, and organic matter chemistry. J. Plant Nutr. Soil Sci. $171,61-82$.

Kusakabe, R., Taniguchi, T., Goomaral, A., Undarmaa, J., Yamanaka, N., Yamato, M. 2018. Arbuscular mycorrhizal fungal communities under gradients of grazing in Mongolian grasslands of different aridity. Mycorrhiza 28 (7), 621-634.

Lange, M., Eisenhauer, N., Sierra, C.A., Bessler, H., Engels, C., Griffiths, R.I., MelladoVazquez, P.G., Malik, A.A., Roy, J., Scheu, S., Steinbeiss, S., Thomson, B.C., Trumbore, S.E., Gleixner, G., 2015. Plant diversity increases soil microbial activity and soil carbon storage. Nat. Commun. 6, 6707.

Liang, C., Balser, T.C., 2008. Preferential sequestration of microbial carbon in subsoils of a glacial-landscape toposequence, Dane County, WI, USA. Geoderma 148, 113-119.

Liang, C., Balser, T.C., 2011. Microbial production of recalcitrant organic matter in global soils: implications for productivity and climate policy. Nat. Rev. Microbiol. 9, 75.

Liang, C., Gutknecht, J.L., Balser, T.C., 2015. Microbial lipid and amino sugar responses to long-term simulated global environmental changes in a California annual grassland. Front. Microbiol. 6, 1-11.

Liang, C., Schimel, J.P., Jastrow, J.D., 2017. The importance of anabolism in microbial control over soil carbon storage. Nat. Microbiol. 2, 17105.

Liang, Z., Olesen, J.E., Jensen, J.L., Elsgaard, L., 2019. Nutrient availability affects carbon turnover and microbial physiology differently in topsoil and subsoil under a temperate grassland. Geoderma 336, 22-30.

Liu, Y., Ma, W., Kou, D., Niu, X., Wang, T., Chen, Y., Chen, D., Zhu, X., Zhao, M., Hao, B., Zhang, J., Yang, Y., Hu, H., 2020. A comparison of patterns of microbial C : N : P stoichiometry between topsoil and subsoil along an aridity gradient. Biogeosciences 17, 2009-2019.

Logemann, J., Graue, J., Köster, J., Engelen, B., Rullkötter, J., Cypionka, H., 2011. A laboratory experiment of intact polar lipid degradation in sandy sediments. Biogeosciences 8, 2547-2560.

Ma, T., Zhu, S., Wang, Z., Chen, D., Dai, G., Feng, B., Su, X., Hu, H., Li, K., Han, W., Liang, C., Bai, Y., Feng, X., 2018. Divergent accumulation of microbial necromass and plant lignin components in grassland soils. Nat. Commun. 9, 3480.

Ma, W., Yang, Y., He, J., Zeng, H., Fang, J., 2008. Above- and belowground biomass in relation to environmental factors in temperate grasslands, Inner Mongolia. Sci. China. Ser. C: Life Sci. 51, 263-270.

Maestre, F.T., Delgado-Baquerizo, Jeffries, M.T.C., Eldridge, D.J., Ochoa, V., Gozalo, B., Quero, J.L., García-Gómez, M., Gallardo, A., Ulrich, W., Bowker, M.A., Arredondo, T., Barraza-Zepeda, C., Bran, D., Florentino, A., Gaitán, J., Gutiérrez, J.R., HuberSannwald, Jankju, E.M., Mau, R.L., Miriti, M., Naseri, K., Ospina, A., Stavi, I., Wang, D., Woods, N.N., Yuan, X., Zaady, E., Brajesh, K.S., 2015. Increasing aridity reduces soil microbial diversity and abundance in global drylands. Proc. Natl. Acad. Sci. 112,
15684-15689.

Mehra, O.P., Jackson, M.L., 1960. Iron oxide removal from soils and clays by a dithionitecitrate system buffered with sodium bicarbonate. Clays Clay Miner. 7, 317-327.

Miltner, A., Bombach, P., Schmidt-Brücken, B., Kästner, M., 2012. SOM genesis: microbial biomass as a significant source. Biogeochemistry 111, 41-55.

Ni, J., Zhang, X.-S., 2000. Climate variability, ecological gradient and the Northeast China Transect (NECT). J. Arid Environ. 46, 313-325.

Olsson, P.A., Rahm, J., Aliasgharzad, N., 2010. Carbon dynamics in mycorrhizal symbioses is linked to carbon costs and phosphorus benefits. FEMS Microbiol. Ecol. 72, 125-131.

Rowland, A.P., Haygart, P.M., 1997. Determination of total dissolved phosphorus in soil solutions. J. Environ. Qual. 26, 410-415.

Rowley, M.C., Grand, S., Verrecchia, É.P., 2018. Calcium-mediated stabilisation of soil organic carbon. Biogeochemistry 137, 27-49.

Rumpel, C., Chabbi, A., Marschner, B., 2012. Carbon storage and sequestration in subsoil horizons: knowledge, gaps and potentials. In: Lal, R. (Ed.), Recarbonization of the Biosphere: Ecosystems and the Global Carbon Cycle. Springer, Berlin Heidelberg, pp. 445-464.

Schiedung, M., Tregurtha, C.S., Beare, M.H., Thomas, S.M., Don, A., 2019. Deep soil flipping increases carbon stocks of New Zealand grasslands. Glob. Chang. Biol. 25, 2296-2309.

Schmidt, M.W.I., Torn, M.S., Abiven, S., Dittmar, T., Guggenberger, G., Janssens, I.A., Kleber, M., Kögel-Knabner, I., Lehmann, J., Manning, D.A.C., Nannipieri, P., Rasse, D.P., Weiner, S., Trumbore, S.E., 2011. Persistence of soil organic matter as an ecosystem property. Nature 478, 49-56.

Schouten, S., Hopmans, E.C., Sinninghe Damsté, J.S., 2013. The organic geochemistry of glycerol dialkyl glycerol tetraether lipids: a review. Org. Geochem. 54, 19-61.

Sinninghe Damsté, J.S., Rijpstra, W.I., Hopmans, E.C., Jung, M.Y., Kim, J.G., Rhee, S.K. Stieglmeier, M., Schleper, C., 2012. Intact polar and core glycerol dibiphytanyl glycerol tetraether lipids of group I.1a and I.1b thaumarchaeota in soil. Appl. Environ. Microbiol. 78 (19), 6866-6874.

Sinninghe Damsté, J.S., Rijpstra, W.I., Hopmans, E.C., Weijers, J.W., Foesel, B.U., Overmann, J., Dedysh, S.N., 2011. 13,16-Dimethyl octacosanedioic acid (iso-diabolic acid), a common membrane-spanning lipid of Acidobacteria subdivisions 1 and 3 . Appl. Environ. Microbiol. 77 (12), 4147-4154.

Six, J., Frey, S.D., Thiet, R.K., Batten, K.M., 2006. Bacterial and fungal contributions to carbon sequestration in agroecosystems. Soil Sci. Soc. Am. J. 70, 555-569.

Sollins, P., Kramer, M.G., Swanston, C., Lajtha, K., Filley, T., Aufdenkampe, A.K., Wagai, R., Bowden, R.D., 2009. Sequential density fractionation across soils of contrasting mineralogy: evidence for both microbial- and mineral-controlled soil organic matte stabilization. Biogeochemistry 96, 209-231.

Sradnick, A., Oltmanns, M., Raupp, J., Joergensen, R.G., 2014. Microbial residue indices down the soil profile after long-term addition of farmyard manure and mineral fertilizer to a sandy soil. Geoderma 226-227, 79-84.

Sun, D., Tan, W., Pei, Y., Zhou, L., Wang, H., Yang, H., Xu, Y., 2011. Late Quaternary environmental change of Yellow River Basin: an organic geochemical record in Boha Sea (North China). Org. Geochem. 42 (6), 575-585.

Tierney, J.E., Schouten, S., Pitcher, A., Hopmans, E.C., Sinninghe Damsté, J.S., 2012. Core and intact polar glycerol dialkyl glycerol tetraethers (GDGTs) in Sand Pond, Warwick, Rhode Island (USA): Insights into the origin of lacustrine GDGTs. Geochim. Cosmochim. Acta 77, 561-581.

Wang, H., Liu, W., Zhang, C.L., Wang, Z., Wang, J., Liu, Z., Dong, H., 2012. Distribution of glycerol dialkyl glycerol tetraethers in surface sediments of Lake Qinghai and surrounding soil. Org. Geochem. 47, 78-87.

Weijers, J.W.H., Schouten, S., Spaargaren, O.C., Sinninghe Damsté, J.S., $2006 a$. Occurrence and distribution of tetraether membrane lipids in soils: implications for the use of the TEX86 proxy and the BIT index. Org. Geochem. 37, 1680-1693.

Weijers, J.W.H., Schouten, S., Hopmans, E.C., Geenevasen, J.A., David, O.R., Coleman, J.M., Pancost, R.D., Sinninghe Damste, J.S., 2006b. Membrane lipids of mesophilic anaerobic bacteria thriving in peats have typical archaeal traits. Environ. Microbiol. 8, 648-657.

Weijers, J.W.H., Schouten, S., van den Donker, J.C., Hopmans, E.C., Sinninghe Damsté, J.S., 2007. Environmental controls on bacterial tetraether membrane lipid distribution in soils. Geochim. Cosmochim. Acta 71, 703-713.

Weijers, J.W.H., Wiesenberg, G.L.B., Bol, R., Hopmans, E.C., Pancost, R.D., 2010. Carbon isotopic composition of branched tetraether membrane lipids in soils suggest a rapid turnover and a heterotrophic life style of their source organism(s). Biogeosciences 7 , 3691-3734.

White, D.C., Davis, W.M., Nickels, J.S., King, J.D., Bobbie, R.J., 1979. Determination of the sedimentary microbial biomass by extractible lipid phosphate. Oecologia 40, 51-62.

Willers, C., Jansen van Rensburg, P.J., Claassens, S., 2015. Phospholipid fatty acid profiling of microbial communities-a review of interpretations and recent applications. J. Appl. Microbiol. 119, 1207-1218.

Wu, E.Q., 2017. Comparative study on grazing ecology in typical steppe between China and Mongolia of Mongolian plateau. Doctor Thesis, Inner Mongolia Agricultural University, Inner Mongolia.

Xie, S., Pancost, R.D., Chen, L., Evershed, R.P., Yang, H., Zhang, K., Huang, J., Xu, Y., 2012. Microbial lipid records of highly alkaline deposits and enhanced aridity associated with significant uplift of the Tibetan Plateau in the Late Miocene. Geology 40, 291-294.

Xiong, D., Shi, P., Zhang, X., Zou, C.B., 2016. Effects of grazing exclusion on carbon sequestration and plant diversity in grasslands of China-a meta-analysis. Ecol. Eng. 94, 647-655.

Yang, H., Pancost, R.D., Dang, X., Zhou, X., Evershed, R.P., Xiao, G., Tang, C., Gao, L., Guo, Z., Xie, S., 2014. Correlations between microbial tetraether lipids and 
environmental variables in Chinese soils: optimizing the paleo-reconstructions in semi-arid and arid regions. Geochim. Cosmochim. Acta 126, 49-69.

Zhang, J.B., Wang, L., Zhao, W., Hu, H.F., Feng, X.J., Muller, C., Cai, Z.C., 2016. Soil gross nitrogen transformations along the Northeast China Transect (NECT) and their response to simulated rainfall events. Sci. Rep. 6, 22830.

Zhang, X., Amelung, W., 1996. gas chromatographic determination of muramic acid, glucosamine, mannosamine, and galactosamine in soils. Soil Biol. Biochem. 28,
1201-1206.

Zhang, Y., Gao, X., Hao, X., Alexander, T.W., Shi, X., Jin, L., Thomas, B.W., 2020. Heavy grazing over 64 years reduced soil bacterial diversity in the foothills of the Rocky Mountains. Canada. Appl. Soil Ecol. 147, 103361.

Zhang, Y., Zheng, N., Wang, J., Yao, H., Qiu, Q., Chapman, S.J., 2019. High turnover rate of free phospholipids in soil confirms the classic hypothesis of PLFA methodology. Soil Biol. Biochem. 135, 323-330. 